Clin. Lab. Haem.

2004, 26, 297-300 CASE REPORT

\title{
Coexistence of congenital red cell pyruvate kinase and band 3 deficiency
}

\author{
R. BRANCA*, *Serviço de Hematologia, Hospital de Crianças Maria Pia, Porto, Portugal \\ E. COSTA*, †Serviço de Bioquímica, Faculdade de Farmácia, Universidade do Porto, Porto, Portugal \\ S. ROCHA $\dagger, \ddagger$ ¥Instituto de Biologia Molecular e Celular da Universidade do Porto, Porto, Portugal \\ H. COELHO*, §Unidade de Biologia Molecular, Hospital Geral de Santo António, Porto, Portugal \\ A. QUINTANILHA $\dagger, t$, \\ J. M. CABEDA§, \\ A. SANTOS-SILVA $†,+$, \\ J. BARBOT*
}

Summary The authors report the case of a 9-year-old Caucasian girl, born in northern Portugal, with chronic nonspherocytic haemolytic anaemia and without family history of anaemia. The aethiological study of this anaemia revealed pyruvate kinase deficiency (PKD), because of two previously described mutations (426Arg $\rightarrow$ Trp and 510Arg $\rightarrow$ Gln). Since the blood smear revealed features not fully compatible with PKD diagnosis, additional tests were performed for the propositus and her parents, namely red blood cell membrane protein analysis. A decrease in proteins band $3(15 \%)$ and $4.2(18 \%)$ was found in the propositus. Her father presented only a decrease in band $3(11 \%)$. Coexistence of PKD and erythrocyte membrane proteins deficiency in the same patient is very uncommon. Our findings suggest that a careful blood smear observation may lead to the identification of a combined deficiency in erythrocyte membrane proteins and enzymopathies.

Keywords Band 3 deficiency, chronic nonspherocytic haemolytic anaemia, hereditary spherocytosis, pyruvate kinase

\section{Introduction}

Pyruvate kinase (PK) deficiency is the most common enzyme abnormality in the erythrocyte glycolytic pathway causing hereditary chronic nonspherocytic haemolytic anaemia. Usually, clinical manifestations are only present in homozygous or compound heterozygous subjects for different gene mutations (Baronciani \& Beutler, 1993; Kanno, Fujii \& Miwa, 1993; Demina et al., 1998; Ferreira et al., 2000). Considering the heterogeneity of the underlying molecular defects, it is not always possible to make a precise genotype/phenotype correlation. Heterozygote car-

Accepted for publication 12 April 2004

Correspondence: Rosa Branca, Serviço de Hematologia, Hospital de Crianças Maria Pia, Rua da Boavista, 827, 4050-111 Porto, Portugal. E-mail: hematologia@hmariapia.min-saude.pt riers of the enzyme deficiency are usually devoid of clinical manifestations (Demina et al., 1998; Ferreira et al., 2000). Red cell morphology is commonly unremarkable, displaying some degree of anisocytosis and polychromatophilia with a variable number of contracted echinocytes (small densely staining spiculated cells), which usually become more numerous after splenectomy (Zanella \& Bianchi, 2000).

Band 3, the red cell anion exchanger, is a member of a widely distributed family of proteins present in many tissues, which play part in many cellular processes involving the exchange transport of anions across membranes (Kollert-Jons et al., 1993; Sahr et al., 1994; Schofield et al., 1994). In red cells, band 3 enhances the ability of blood to carry carbon dioxide from the tissues to the lungs, and contributes to the stability and integrity of the cell. Band 3 is the most representative protein in $\mathrm{RBC}$ membrane and its deficiency is associated with 
20-40\% (Hassoun \& Palek, 1996) of all hereditary spherocytosis cases, as well as with a few elliptocytosis cases (namely southeast Asian ovalocytosis) (Jarolim et al., 1991).

We describe a concomitant PK and band 3 deficiency in a female child with chronic haemolytic anaemia.

\section{Case report}

The patient is a 9-year-old Caucasian girl born in northern Portugal of nonconsanguineous parents with no known family history of anaemia. She developed jaundice in the first $24 \mathrm{~h}$ of life needing no specific treatment, and had a history of chronic anaemia with sporadic iron supplementation.

We first saw the patient when she was 6 years old. She presented normal physical and intellectual development. Her skin was pale, the sclera slightly icteric and the spleen was palpable $2.5 \mathrm{~cm}$ below the costal margin.

The basic haematological studies showed anaemia $(9.8 \mathrm{~g} / \mathrm{dl})$, reticulocytosis $\left(398 \times 10^{9} / \mathrm{l}\right)$, high levels of total and indirect bilirrubin $(85 \mu \mathrm{mol} / \mathrm{L}$ and $80.5 \mu \mathrm{mol} / \mathrm{L}$, respectively), slightly high lactate dehydrogenase level
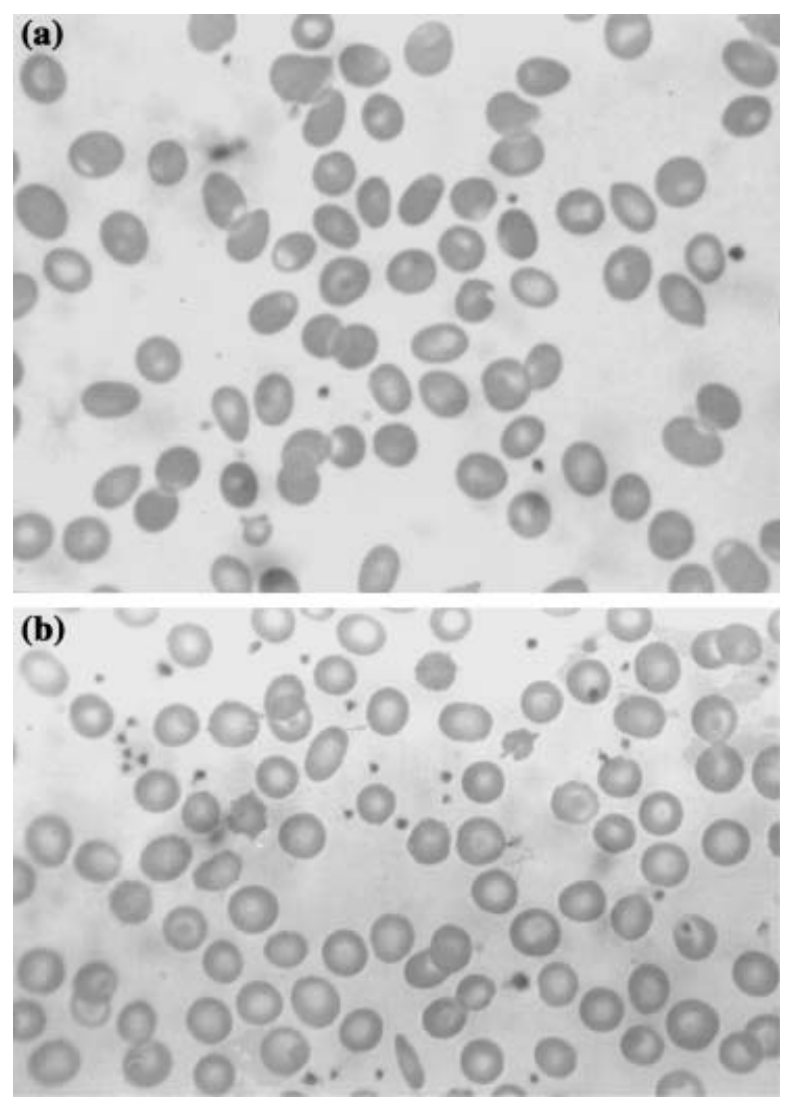

Figure 1. Blood smear of the propositus, before (a) and after (b) splenectomy.
(463 IU/l) and undetectable haptoglobin levels. The blood smear revealed red cell anisocytosis and anisochromia with some elliptical and few tear drop-shaped erythrocytes (Figure 1).

The aethiological study of this haemolytic anaemia revealed a reduced PK activity of $2.2 \mathrm{IU} / \mathrm{g} \mathrm{Hb}$ [normal range (average $\pm 2 \quad \mathrm{SD}$ ): $9.35 \pm 2.3 \mathrm{IU} / \mathrm{g} \mathrm{Hb}]$. The activity of the other erythrocyte glycolytic enzymes, as well as the osmotic fragility test and the haemoglobin electrophoresis pattern were normal, in the patient and in her parents. Both parents presented PK activities in the heterozygous range (father: $3.0 \mathrm{IU} / \mathrm{g} \mathrm{Hb}$; mother: $3.2 \mathrm{IU} / \mathrm{g} \mathrm{Hb}$ ). A direct sequencing of PKLR gene revealed a compound heterozygosity in the patient for two previously described mutations (Figure 2), 1276T (426Arg $\rightarrow$ Trp) and 1529A (510Arg $\rightarrow$ Gln). Molecular analysis of the TATA-box region of the UDP-glucuronosyltransferase-1 (UGT1A1) gene was made, revealing heterozygosity for a TA insertion $\left[(\mathrm{TA})_{6} /(\mathrm{TA})_{7}\right]$ (Figure 3).

Two years later, her haemoglobin levels dropped further (first year average $\mathrm{Hb}: 9.15 \mathrm{~g} / \mathrm{dl}$; second year average $\mathrm{Hb}$ : $8.2 \mathrm{~g} / \mathrm{dl})$. At this time, splenectomy was performed. Afterwards, haemoglobin levels showed a rise to stable values above $10 \mathrm{~g} / \mathrm{dl}$; reticulocyte count increased to an average of $688 \times 10^{9} / \mathrm{l}$, and total bilirrubin levels fell to around $29.2 \mu \mathrm{mol} / \mathrm{L}$. Red blood cell morphology, as expected after splenectomy, acquired slight different features with the presence of some poikilocytes and echinocytes. Few elliptocytes were still seen (Figure 1), which led us to search for membrane protein deficiencies. The erythrocytes were isolated and their membranes obtained and prepared according to Dodge, Mitchell and Hanahan (1963). Protein concentration of the membrane suspensions was determined (Bradford, 1976), and, after heat denaturation, proteins were submitted to polyacrylamide gel electrophoresis with sodium dodecyl sulphate (SDSPAGE), according to the methods of Laemmli (1970) and Fairbanks, Steck and Wallach (1971). Proteins were stained with Coomassie blue, and the gels were analysed by a densitometer coupled to an image analysis software (Bio-profil; Vilbert Lourmat, Torcy Marne-la-Vallée, France). We found a 15\% decrease of band 3 and an $18 \%$ decrease of protein 4.2 in the patient, whereas the father presented only a $11.3 \%$ decrease in band 3 (Figure 4), suggesting a primary band 3 deficiency in both.

\section{Discussion}

Unlike PK deficiency, which is a rare condition, band 3 deficiency is one of the most frequent causes of hereditary

(C) 2004 Blackwell Publishing Ltd, Clin. Lab. Haem., 26, 297-300 
(a)

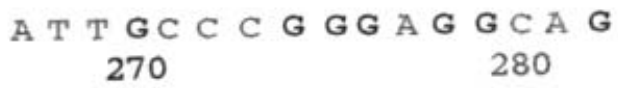

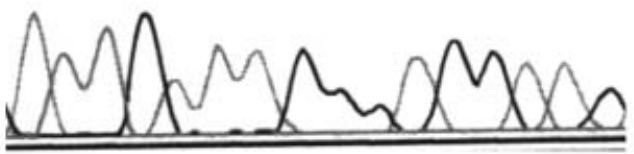

(b)
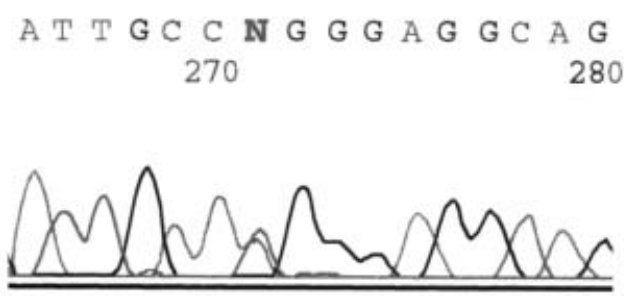

(c)

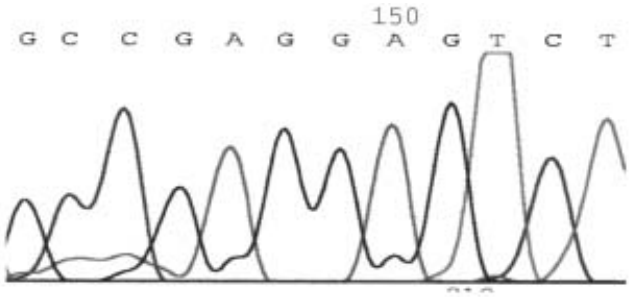

(d)

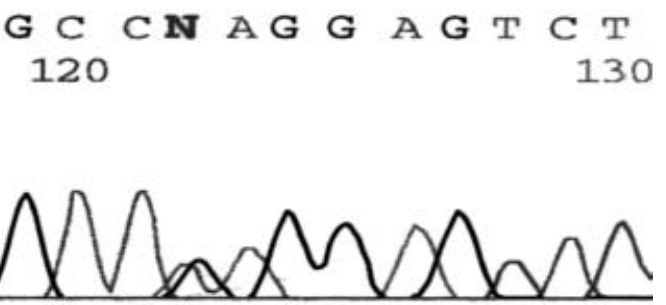

Figure 2. Extract of direct sequencing of exon 10 and 11 of the PKLR gene. (a) Normal sequencing of exon 10. (b) Patient sequencing of exon 10, with $\mathrm{C}$ and T peaks in nucleotide 1276 (426Arg $\rightarrow$ Trp). (c) Normal sequencing of exon 11. (d) Patient sequencing of exon 11, with $\mathrm{G}$ and A peaks in nucleotide 1529 (510Arg $\rightarrow$ Gln).

(a)

80

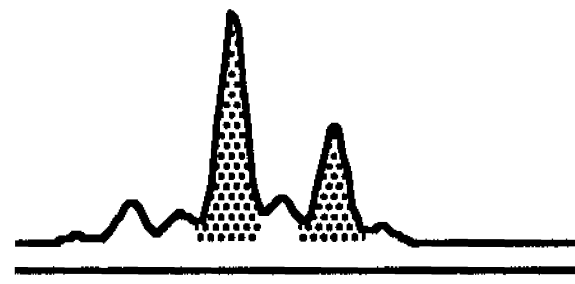

(b)

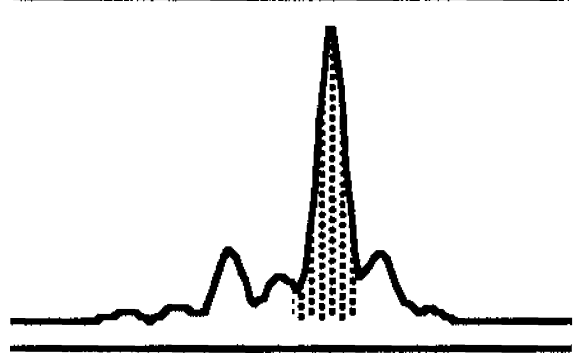

Figure 3. Screening for UGT1A1 promoter variants, performed by fluorescence-labelled polymerase chain reaction (PCR). The amplified DNA fragment were separated by automated capillary electrophoresis and analysed with ABI GeneScan program (Applied Biosystems, Foster City, CA, USA). (a) Propositus sample heterozygous for the mutant (TA)7 allele. (b) Control sample homozygous for the (TA)7 allele.

haemolytic anaemia. The combination of both is very uncommon. To our knowledge, only one report by Zarza et al. (2000) describes the combination of partial band 3

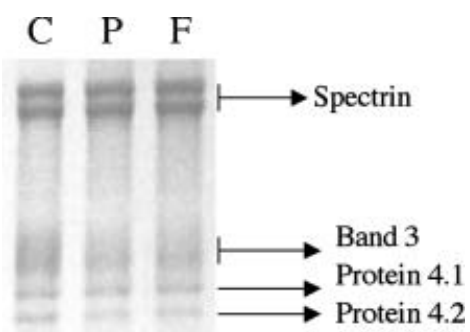

Figure 4. Red cell membrane protein profiles in sodium dodecyl sulphate polyacrylamide gel electrophoresis (SDS-PAGE) gels, presented by a control $(\mathrm{C})$, propositus $(\mathrm{P})$ and father $(\mathrm{F})$.

and protein 4.2 deficiency with heterozygosity for a mutation in the PKLR gene. In the present case, the patient presented a PK deficiency, with compound heterozygosity for two PKLR mutations, combined with band 3 and protein 4.2 deficiency.

In the first approach to the patient, the clinical and, in particular, the laboratorial features were not suggestive of a membrane protein deficiency underlying the chronic haemolytic anaemia presented by the patient. The only feature present in this case, which made us suspect of something more than just PK deficiency, was the observation of elliptocytic cells in the blood smear. Moreover, 
the father, who was heterozygous for PK deficiency and who also showed to present a band 3 deficiency, had no remarkable morphological changes in the blood smear. We did not find in the literature detailed descriptions of other cases of compound heterozygosity for the two described PK mutations, to which compare the clinical and blood smear features presented by our patient.

After splenectomy of the propositous, her haemoglobin levels stabilized at a higher level. This was accompanied by an increase in the number of reticulocytes, which is a common feature postsplenectomy in PK deficiency (Zanella \& Bianchi, 2000).

The most common genetic variant of UGT1A1 gene, which is the main cause of Gilbert's Syndrome in the Portuguese population (Costa et al., 2002a), is a TA insertion in the repetitive TATA-box of the gene promoter, which normally consists of six repeats. In the present case, heterozygosity for this TA insertion was also found. This heterozygosity is thought to influence, albeit marginally, the bilirrubin levels in patients with chronic haemolytic anaemia (Costa et al., 2002b).

In PK deficiency, genotype/phenotype correlation is difficult to establish. There is a great variability in the possible combinations of the mutant alleles, and, even in patients with the same known genotype (either in homozygosity or compound heterozygosity), a significant variability in phenotype is observed. Coinheritance of erythrocyte membrane protein defects could influence this observed variability. In our case, it is not possible to demonstrate the interference of the present membrane protein defect with the clinical picture shown by the patient. Nevertheless, we believe that a careful blood smear observation could lead to the identification of combined enzyme and membrane protein deficiencies. By doing so, it could be possible to better understand the variability of the phenotypic manifestations and the mutual interference of both deficiencies.

In conclusion, our report emphasizes the importance of a careful blood smear observation in cases of chronic haemolytic anaemia, and the need for additional studies, whenever features do not entirely fit within the initially proposed diagnosis.

\section{References}

Baronciani L. \& Beutler E. (1993) Análisis of pyruvate kinasedeficiency mutations that produce nonspherocytic hemolytic anemia. Proceedings of the National Academy of Sciences of the United States of America 90, 4324-4327.

Bradford M.M. (1976) A rapid and sensitive method for the quantitation of microgram quantities of protein utilizing the principle of protein dye binding. Analytical Biochemistry 72, $248-254$.

Costa E., Vieira E., Santos-Silva E., Barbot J. \& dos Santos R. (2002a) TATA-box polymorphism in the uridine diphosphate glucuronosyl transferase gene in Portuguese patients with a clinical diagnosis of Gilbert's syndrome. Haematologica 87(04), ELT21.

Costa E., Pinto R., Vieira E., Polo S., Sarmento A.M., Oliveira I., Pimenta R., Dos Santos R. \& Barbot J. (2002b) Influence of Gilbert's syndrome on serum bilirubin levels and gallstone formation in children with chronic hemolytic disease. Anales Expanoles de Pediatria 57, 529-533.

Demina A., Varughese K.I., Barbot J., Forman L. \& Beutler E. (1998) Six previously undescribed pyruvate kinase mutations causing enzyme deficiency. Blood 92, 647-652.

Dodge J.T., Mitchell C. \& Hanahan D.J. (1963) The preparation and chemical characteristics of hemoglobin-free ghosts of human erythrocytes. Archives of Biochemistry and Biophysics 100, 119-130.

Fairbanks G., Steck T.I. \& Wallach D.F.H. (1971) Electrophoresis of the major polypeptides of the human erythrocyte membrane. Biochemistry 10, 2606.

Ferreira P., Morais L., Costa R., Resende C., Paz-Diaz C., Araújo F., Costa E., Barbot J. \& Vilarinho A. (2000) Hydrops fetalis associated with erythrocyte pyruvate kinase deficiency. European Journal of Pediatrics 159, 481-482.

Hassoun H. \& Palek J. (1996) Hereditary spherocytosis: a review of the clinical and molecular aspects of the disease. Blood Reviews 10, 129-147.

Jarolim P., Palek J., Amato D., Hassan K., Sapak P., Nurse G.T., Rubin H.L., Zhai S., Sahr K.E. \& Liu S.C. (1991) Deletion in erythrocyte band 3 gene in malaria-resistant southeast Asian ovalocytosis. Proceedings of the National Academy of Sciences of the United States of America 88, 11022-11026.

Kanno H., Fujii H. \& Miwa S. (1993) Low substrate affinity of pyruvate kinase variant (PK Sapporo) caused by a single amino acid substitution (426Arg $\rightarrow$ Gln) associated with hereditary hemolytic anemia. Blood 81, 2439-2441.

Kollert-Jons A., Wagner S., Hubner S., Appelhans H. \& Drenckhalm D. (1993) Anion exchanger 1 in human kidney and oncocytoma differs from erythroid AEI in its NH2 terminus. American Journal of Physiology 265, F813-F821.

Laemmli U.K. (1970) Cleavage of structural proteins during the assembly of the head of bacteriophage T4. Nature 227, 680685.

Sahr K.E., Taylor V.M., Daniels B.P., Rubin H.L. \& Jarolim P. (1994) The structure and organization of the human erythroid anion exchanger (AEI) gene. Genomics 24, 291-501.

Schofield A.E., Martin P.G., Spillett D. \& Tanner M.J.A. (1994) The structure of the human red blood cell anion exchanger (EPB3, AEI, band 3) gene. Blood 84, 2000-2012.

Zanella A. \& Bianchi P. (2000) Red cell pyruvate kinase deficiency: from genetics to clinical manifestations. Baillière's Clinical Haematology 13, 57-81.

Zarza R., Moscardo M., Alvarez R., Garcia J., Morey M., Pujades A. \& Vives-Corrons J.L (2000) Co-existance of hereditary spherocytosis and a new red cell pyruvate kinase variant: PK Mallorka. Haematologica 85, 227-232. 